\title{
VARIABILIDADE E DIVERGÊNCIA GENÉTICA ENTRE GENÓTIPOS DE TUCUMANZEIRO-DO-PARÁ (Astrocaryum vulgare Mart.) PROMISSORES PARA A PRODUÇÃO DE FRUTOS POR MARCADORES RAPD ${ }^{1}$
}

\author{
NATÁLIA PADILHA DE OLIVEIRA², MARIA DO SOCORRO PADILHA DE OLIVEIRA³, \\ ELISA FERREIRA MOURA ${ }^{3}$
}

RESUMO - O objetivo deste trabalho foi estimar a variabilidade e a divergência genética entre genótipos de tucumanzeiro-do-pará promissores para a produção de frutos por marcadores de RAPD. Foram coletadas amostras de folhas de 29 plantas-matrizes selecionadas no Banco Ativo de Germoplasma da Embrapa Amazônia Oriental, com base na produção de frutos por planta, mas com pronunciadas variações para outras características. As amostras de DNA foram amplificadas por 24 iniciadores RAPD e analisadas por três métodos multivariados, usando a matriz de dissimilaridades genéticas obtidas pelo complemento aritmético do coeficiente de Jaccard. Foram gerados 332 marcadores moleculares que expressaram 98,5\% de polimorfismo. Os marcadores RAPD apresentaram poder de discriminação eficiente entre os 29 genótipos avaliados, constatando-se distância genética média entre os genótipos de $51,7 \%$, variando entre $26,9 \%$ e $71,5 \%$. A maior média de distância ocorreu entre o genótipo 22 e os demais, com 66,8\%. Os genótipos formaram oito e quinze grupos distintos, possivelmente grupos heteróticos, pelos métodos de agrupamentos UPGMA e Tocher, respectivamente. As análises das coordenadas principais confirmaram a alta variabilidade entre os genótipos. Os marcadores moleculares utilizados permitiram a identificação de ampla variabilidade e forte divergência genética entre os genótipos com ausência de duplicatas, o que possibilita a indicação desses materiais para compor programa de melhoramento genético para a produção de frutos.

Termos para indexação: Palmeira, Amazônia, polimorfismo, dissimilaridade, análises multivariadas.

\section{VARIABILITY AND GENETIC DIVERGENCE AMONG FIBER PALM TREE (Astrocaryum vulgare Mart.) GENOTYPES FOR FRUIT YIELD BY RAPD MARKERS}

\begin{abstract}
The objective of this study was to estimate the variability and divergence among fiber palm tree genotypes promising for fruit yield by RAPD markers. Leaf samples from 29 plants, selected in the Active Germplasm Bank from Embrapa Eastern Amazon, were collected based in the fruit yield, but with variations by other characteristics related to production. The samples of these DNA were amplified with 24 primers and analyzed by three multivariate methods using the matrix of genetic dissimilarities obtained by arithmetic complement of the Jaccard index. 332 molecular markers expressing polymorphism of $98.5 \%$ were obtained. The RAPD markers presented efficient discriminating power among the 29 evaluated genotypes, determining an average genetic distance among them of $51.7 \%$ ranging from $26.9 \%$ to $71.5 \%$. The highest mean of distance occurred between genotype 22 and the remaining genotypes, with $66.8 \%$. Eight and fifteen different clusters, possibly heterotic groups were formed by the UPGMA and Tocher methods, respectively. The principal coordinate analyses confirmed the great variability among genotypes. The markers used permitted identification of variability and genetic divergence among genotypes with absence of duplicates, allowing the indication of this material in breeding programs for fruit yield.
\end{abstract}

Index terms: Palm, Amazon, polymorphism, dissimilarity, multivariate analysis.

'(Trabalho 132-11). Recebido em: 20-04-2011. Aceito para publicação em: 05-12-2011.

${ }^{2}$ Mestranda em Genética e Melhoramento de Plantas, UFLA, Bolsista do CNPq. E-mail:natybiologia2006@gmail.com

${ }^{3}$ Embrapa Amazônia Oriental, Trav. Dr. Enéas Pinheiro, S/Nº, Belém, Pará, 66095-100, E-mails: spadilha@cpatu.embrapa.br, elisa@cpatu.embrapa.br 


\section{INTRODUÇÃO}

O tucumanzeiro-do-pará (Astrocaryum vulgare Mart.) é uma palmeira, nativa da América do Sul, oleaginosa, que tem como característica marcante a presença de espinhos pretos e flexíveis em quase todas as partes da planta. Seus frutos apresentam grande potencial socioeconômico à população amazônica, pelas diversas utilidades na culinária, no artesanato, na alimentação de animais domésticos e na produção de óleo (VILLACHICA et al., 1996). Nessa região, ocorre predominantemente em Latossolo Amarelo e em Neossolos Quartzarênicos, onde apresenta ampla variação fenotípica para presença ou não de perfilhos, número, tamanho e forma de espinhos, peso, tamanho, forma e cor dos frutos maduros, dentre outras, e com produção média de cinco cachos por planta e de 232 frutos por cacho (LLERAS et al., 1983; CYMERYS, 2005). No entanto, como a maioria das palmeiras amazônicas produtoras de frutos comestíveis, ainda é explorada extrativamente, em decorrência da escassez de informações agronômicas que possibilitem seu cultivo de forma sustentável (CLEMENT et al., 2005).

Para espécies perenes pouco conhecidas, a coleta de materiais reprodutivos para a formação de Bancos de Germoplasma constitui-se em etapa primordial na domesticação, por proporcionar a realização de estudos básicos sobre o material conservado que possam subsidiar programas de melhoramento genético (VILLELA-MORALES et al., 1997). No caso do tucumanzeiro-do-pará, coletas de germoplasma foram realizadas durante a década de 80 , o que viabilizou a implantação do primeiro Banco Ativo de Germoplasma dessa espécie, em 1985 (LIMA; COSTA, 1991). Nesse banco, foram selecionadas plantas-matrizes promissoras com base no caráter produção de frutos por planta. Essas matrizes foram propagadas por sementes, em que cada matriz constituiu uma progênie, para formarem a primeira população melhorada. No entanto, para a realização de um programa de melhoramento eficiente dessa palmeira, torna-se necessário reunir o maior número possível de informações relevantes sobre os indivíduos selecionados e se os mesmos podem ser utilizados na formação da população-base.

Estudos sobre a variabilidade e a divergência genética são essenciais para avançar novos ciclos de seleção, na identificação e na relação entre os progenitores que possam gerar maior efeito heterótico em combinações híbridas e na identificação de possíveis duplicatas (CRUZ et al., 2004). Para Garcia (2002), o nível de heterose está diretamente relacionado às distâncias genéticas entre os progenitores. Tais procedimentos podem ser avaliados por meio de vários marcadores, como os morfológicos e os moleculares, sendo estes últimos mais vantajosos por não sofrerem influência direta do ambiente, como acontece com os morfológicos, e por disponibilizarem informações com mais precisão e em menor tempo (DIAS et al., 1997). Marcadores RAPD (Randomly Amplified Polymorphic DNA), descritos inicialmente pelos grupos de pesquisadores William et al. (1990) e Welsh e McClelland (1990), são marcadores moleculares dominantes que se baseiam na técnica de PCR (Polymerase Chain Reaction), sendo úteis em análises genéticas de várias espécies, principalmente nas pouco conhecidas, como é o caso do tucumã-dopará (GRATTAPAGLIA, 2007). Esses marcadores apresentam vantagens por sua simplicidade, rapidez na obtenção dos dados, baixo custo se comparado a outras técnicas moleculares, além de demandar pequenas quantidades de DNA, não necessitar de sondas radioativas e ter aplicabilidade imediata a qualquer tipo de organismo (CAIXETA et al., 2006).

Na avaliação da variabilidade e da divergência genética por meio de marcadores moleculares, as relações entre os genótipos quase sempre são visualizadas por métodos hierárquicos, como os agrupamentos. Porém, outros métodos hierárquicos e não hierárquicos podem ser utilizados, os quais são baseados em medidas de similaridades ou dissimilaridades (CRUZ et al., 2004). Estudos dessa natureza com a utilização de marcadores moleculares têm sido realizados para algumas espécies de palmeiras com o intuito de verificar as relações genéticas entre as características e as regiões amplificadas pelos marcadores, como também na identificação de parentais divergentes como forma de maximizar a heterose em hibridações (DAHER et al., 2002; ISENSEE et al., 2007; ROSSATO et al., 2007). Entretanto, para o tucumã-do-pará, relatos dessa natureza não foram encontrados.

Este trabalho teve como objetivos avaliar a variabilidade e a divergência genética entre plantasmatrizes de tucumanzeiro-do-pará por meio de marcadores RAPD e comparar três metodologias de agrupamento.

\section{MATERIAL E MÉTODOS}

Foram coletados folíolos de folhas recémabertas de 29 plantas-matrizes de tucumã do Banco Ativo de Germoplasma existente no Brasil, BAG Tucumã, estabelecido na sede da Embrapa Amazônia Oriental, em Belém-PA (Tabela 1). Esse banco foi implantado a partir de novembro de 1985, após a 
realização de várias coletas nos Estados do Pará - nas microrregiões do nordeste paraense e do Marajó - e do Maranhão, sendo constituído por 182 plantas (LIMA; COSTA, 1991). As plantas-matrizes foram selecionadas para a produção de frutos por planta, com base na média do BAG $\left(\mu_{0}=5,93 \mathrm{~kg}\right)$, de modo que todas apresentam altos rendimentos de frutos por cacho ( $R F C \geq 84,3 \%$ ) e de polpa por fruto ( $R P F \geq 49,1 \%$ ), características desejáveis ao mercado de frutos. Após a coleta, as 29 amostras de folíolos foram colocadas em sacos de plástico identificados, armazenadas em caixas térmicas com gelo e transportadas para o Laboratório de Genética Molecular dessa instituição para a extração do DNA genômico.

O DNA foi extraído de três segmentos de folíolo de cada amostra, de acordo com o protocolo CTAB a 2\% (Cetil Trimetil Brometo de Amônio), estabelecido por Doyle e Doyle (1987), com modificações feitas por Costa e Oliveira (2002). Pedaços das lâminas foliares sem as nervuras centrais e os bordos foram macerados em almofariz de porcelana, contendo nitrogênio líquido e PVP (polivinilpirrolidona), até a obtenção de um pó fino. Cerca de 300 mg do macerado foram transferidos para tubos Falcon mantidos sob refrigeração e, posteriormente, acrescidos de $300 \mu 1$ de tampão de extração e agitados em vórtex. Os tubos foram incubados em banho-maria a $65^{\circ} \mathrm{C}$ por $60 \mathrm{~min}$, sendo agitados a cada $10 \mathrm{~min}$. Em seguida, foi adicionado às amostras clorofórmio: álcool isoamílico (24:1) e, após homogeneização, por meio de agitação lenta de $10 \mathrm{~min}$, as mesmas foram centrifugadas a $5.000 \mathrm{rpm}$ por $10 \mathrm{~min}$. O sobrenadante (fase aquosa) foi coletado e transferido a outro tubo Falcon, acrescido de $3 \mathrm{ml}$ de etanol a $95 \%$ gelado e centrifugado por $10 \mathrm{~min}$ a $5.000 \mathrm{rpm}$. A parte líquida foi descartada, e o precipitado, acrescido de $3 \mathrm{ml} \mathrm{de}$ etanol a $70 \%$ gelado e centrifugado a $5.000 \mathrm{rpm}$ por $10 \mathrm{~min}$. A fase líquida foi novamente descartada, e o precipitado, posto para secar em temperatura ambiente por aproximadamente $18 \mathrm{~h}$. Depois de seco, o DNA foi dissolvido em $300 \mu 1$ de TE (Tris-HCl $10 \mathrm{mM}$, pH 8,0; EDTA $1 \mathrm{mM}$ ) contendo RNase (na proporção de $10 \mu 1$ de RNase por $1 \mathrm{ml}$ de TE). As amostras foram armazenadas em freezer a $-10^{\circ} \mathrm{C}$. A quantificação do DNA foi realizada em gel de agarose a $1 \%$ corado com brometo de etídio, imerso em cuba horizontal contendo TBE $1 \mathrm{X}$ e com eletroforese a $100 \mathrm{~V}$ por 30 min. A comparação das bandas obtidas foi realizada por três padrões do DNA do fago $\lambda(50 ; 100$ e 200 ng. $\left.\mu 1^{1-1}\right)$. As amostras de DNA utilizadas nas reações foram diluídas para a concentração de $10 \mathrm{ng} . \mu \mathrm{l}^{-1}$.

As reações de RAPD foram realizadas para 24 iniciadores decâmeros da Operon Technologies (Invitrogen) selecionados por Oliveira et al. (2009) para a espécie (Tabela 2). As reações PCR foram preparadas em microtubos de $0,2 \mathrm{ml}$ com volume final de $15 \mu \mathrm{l}$ (35 ng de DNA genômico total; $50 \mu \mathrm{M}$ de cada dNTP; 1,3 mM de primer; 10 mg. $\mathrm{ml}^{-1}$ de BSA; 1 unidade de Taq polimerase; e tampão contendo $\mathrm{MgCl}_{2}$ fornecido pela Invitrogen) e colocadas em amplificador Amplitherm TX96 com programação para 40 ciclos, conforme protocolo de Williams et al. (1990) com modificações (OLIVEIRA et al., 2007). Os produtos amplificados foram aplicados em gel de agarose a $1 \%$ corado com brometo de etídio, submersos em tampão TBE $1 \mathrm{X}$ e separados por eletroforese horizontal conduzida a $100 \mathrm{~V}$ por 90 min. Os géis foram visualizados em transiluminador de luz UV, e as imagens dos marcadores RAPD, capturadas digitalmente.

Os marcadores RAPD gerados foram analisados de acordo com a presença (1) ou ausência (0) de bandas. As bandas que migraram a mesma distância no gel foram consideradas como pertencentes ao mesmo loco, e os dados obtidos foram organizados em planilha Excel. A matriz binária estabelecida foi utilizada na obtenção das estimativas de similaridades genéticas ( $\mathrm{g}$ ) entre os pares dos genótipos, com base no coeficiente de Jaccard (REIF et al., 2005), por meio do software NTSYS-pc 2.1 (ROHLF, 2000), obtida por meio da expressão:

$$
\hat{s} g_{i j}=\frac{a}{(a+b+c)}
$$

As estimativas de similaridades foram convertidas em dissimilaridades $\left(d g_{4}\right)$ por meio do complemento aritmético, utilizando a seguinte expressão:

$$
d g_{i j}=1-\hat{s} g_{i j}
$$

A visualização das dissimilaridades genéticas entre os genótipos foi organizada por três métodos: 0 dendrograma gerado pelo método UPGMA (Unweighted pair-group method averages) (SNEATH; SOKAL, 1973), no software NTSYS-pc 2.1, cujo ponto de corte foi feito com base na dissimilaridade média $\left(d g_{\mathrm{m}}\right)$ para indicar os grupos divergentes obtida a partir da seguinte expressão:

$$
d g_{m}=\sum d g_{i j} / N \text { com a confiabilidade dos }
$$
grupos formados avaliada pelo teste $\mathrm{Z}$ de Mantel; o de otimização de Tocher, utilizando o programa GENES; e a dispersão gráfica, usando o método das coordenadas principais com análise bidimensional realizada no NTSYS 2,1-pc. Pois, segundo Arriel et al. (2006), a interpretação por mais de um método reduz inferências errôneas. 


\section{RESULTADOS E DISCUSSÃO}

As reações de PCR realizadas nas amostras de DNA das 29 plantas-matrizes com base nos 24 iniciadores arbitrários proporcionaram a amplificação de 332 marcadores e média de 13,8 bandas por iniciador (Tabela 2). Desse total, 327 produtos de amplificação foram polimórficos, com média de 13,6 bandas por primer, o que representa alto nível de polimorfismo $(98,5 \%)$. Dos iniciadores utilizados, apenas quatro (OPA-08, OPA-19, OPO-12 e OPAB01) não apresentaram $100 \%$ de polimorfismo, sendo o menor e o maior número de marcadores registrados nos iniciadores OPAR-07 e OPAZ-05, com 7 e 21 bandas, respectivamente. Oliveira et al. (2007) encontraram menor número de produtos de amplificação, quando avaliaram a diversidade genética em 116 acessos de açaizeiro por 28 iniciadores RAPD, mas detectaram $100 \%$ de polimorfismo em todos os iniciadores. Insensee et al. (2007) constataram um número bem menor de bandas polimórficas, quando aplicaram 17 iniciadores RAPD em 88 pupunheiras e associaram a presença de indivíduos já selecionados na amostra avaliada. Bicalho et al. (2008), estudando a variabilidade e a divergência entre clones de Hevea brasiliensis, também por marcadores RAPD, obtiveram médias de bandas e polimorfismo bem abaixo do detectado neste estudo. Junqueira et al. (2010) também detectaram baixo polimorfismo $(40,54 \%)$ em 16 genótipos de pitaya com diferentes níveis de produção e consideraram a existência de baixa variabilidade genética entre os genótipos.

Esses resultados indicam que, apesar de as 29 plantas-matrizes terem sido selecionadas para a produção de frutos, esse grupo de genótipos ainda apresenta alto grau de polimorfismo, como exemplificado na Figura 1, o que sugere grande heterozigose entre esses materiais, fornecendo indícios de que possuam ampla variabilidade e expressem forte divergência genética. Esse alto polimorfismo também pode estar associado ao fato de a espécie ainda não ser domesticada e por ter considerável taxa de polinização cruzada. Ressalta-se ainda que os genótipos selecionados são oriundos de sete procedências e que originalmente expressam distinção para outras características morfológicas (Tabela 1). Assim sendo, é plausível inferir que os fragmentos amplificados no estudo podem ser considerados suficientes para a quantificação da variabilidade e da divergência genética entre as matrizes de tucumã.

A matriz de distâncias genéticas obtida pelo complemento de similaridade de Jaccard mostra a relação entre os 406 pares formados pelas plantasmatrizes, onde se verifica que as dissimilaridades variaram de 0,269 a 0,715 , com média de 0,517 (Tabela 3). A menor distância foi registrada entre as matrizes 2 e 5, ambas procedentes de Marudá-PA, cujas características agronômicas guardam grande semelhança, diferindo apenas na coloração dos frutos maduros (Tabela 1). Por sua vez, a maior distância foi obtida entre as matrizes 16 e 22 , de procedências distintas e com diferenças também para várias características agronômicas, como perfilhamento, precocidade e coloração dos frutos maduros. As médias das distâncias genéticas das 29 matrizes variaram de 0,467 a 0,668 , com a matriz 22, procedente de SalinópolisPA, apresentando a maior distância em relação às demais (Tabela 3). Serra et al. (2006), ao avaliarem a divergência genética entre 34 castanheiras-do-brasil, encontraram distância genética média menor $(0,39)$ e a menor distância genética também entre indivíduos de mesma procedência. Esses resultados reforçam que o material avaliado apresenta considerável variabilidade e divergência genética, pelo menos em uma amostra de seu genoma. Com base no exposto, é possível admitir que tais matrizes possam ser úteis na formação de uma população-base, para iniciar um programa de melhoramento genético dessa palmeira por seleção recorrente intrapopulacional, uma vez que as matrizes são produtivas e divergentes, e que os cruzamentos entre os genótipos mais divergentes possam fornecer consideráveis ganhos genéticos.

As distâncias genéticas obtidas pelos marcadores moleculares considerados, com base no dendrograma, evidenciam a formação de, pelo menos, cinco grupos distintos, com dois grupos apresentando vários subgrupos (Figura 2). Porém, considerando-se o ponto de corte $\left(d g_{m}=0,517\right)$, é possível a delimitação de oito grupos: $\mathrm{O}$ grupo I contendo a matriz 22, procedente de Salinópolis-PA, e que apresenta precocidade, reduzida capacidade de perfilhamento, frutos do tipo comum e produção de 11,5 kg; o II, pela matriz 19, oriunda de Salinópolis-PA, também com reduzida capacidade de perfilhamento, frutos do tipo grande e com produção de $12 \mathrm{~kg}$; o III, constituído pelas matrizes 29; 28; 27 e 26, todas de Bragança- PA, possuindo média a alta capacidade de perfilhamento, frutos do tipo cará e com produção variando de 6,2 $\mathrm{kg}$ a $14,6 \mathrm{~kg}$; o IV, pelas matrizes $25 ; 24 ; 23 ; 21$ e 20 , a maioria de Salinópolis-PA, com reduzida a média capacidade de perfilhamento, precocidade, de fruto comum e com produção oscilando de $6,9 \mathrm{~kg}$ a 13,5 $\mathrm{kg}$; o V, representado pela matriz 12 , procedente de Curuçá-PA, com média capacidade de perfilhamento, frutos do tipo comum e produção de $10,5 \mathrm{~kg}$; o VI, representado pelo maior número de matrizes $(17 ; 16$; $15 ; 14 ; 13 ; 18 ; 11 ; 10 ; 9 ; 8 ; 7 ; 6 ; 3 ; 5$ e 2) de várias localidades, todas com frutos tipo comum, exceto a 
18 , e com produções variando de $7,3 \mathrm{~kg}$ a $20,3 \mathrm{~kg}$; o VII, pela matriz 4, procedente de Marudá-PA, com baixa capacidade de perfilhamento, frutos do tipo comum e produção de $17,3 \mathrm{~kg}$; e o VIII, pela matriz 1, de Marapanim-PA, com baixa capacidade de perfilhamento e produção de $8,6 \mathrm{~kg}$. Com exceção dos grupos III e IV, constatou-se pouca tendência de agrupamentos por procedência. No entanto, houve tendência de agrupamento para as características agronômicas, especialmente para o tipo de fruto comum (VI grupo), plantas precoces (grupo IV) e plantas anãs com fruto tipo cará (grupo III). O dendrograma teve alta confiabilidade estatística $(\mathrm{r}=0,86$ e $\mathrm{P} \leq 0,0001$ ) pelo teste $\mathrm{Z}$ de Mantel, confirmando a alocação adequada dos genótipos nos grupos. Resultados concordantes foram encontrados por Daher et al. (2002), quando analisaram a divergência genética entre genótipos de coqueiro, e Oliveira et al. (2007) em acessos de açaizeiro. Já a formação de poucos grupos foi mencionada por Serra et al. (2006) para castanheira-do-brasil; Insensee et al. (2007) para pupunheiras e Junqueira et al. (2010) para pitaya.

Pelo método de Tocher, as dissimilaridades genéticas permitiram a distribuição das 29 plantasmatrizes em quinze grupos divergentes: o quatorze, constituído por duas matrizes, e o último, por apenas uma (Tabela 4). Nesse caso, observou-se tendência da formação dos grupos por procedência, como também para algumas características agronômicas, como perfilhamento, tipo e coloração dos frutos. A planta-matriz 28, que formou o grupo isolado, é procedente de Bragança-PA, e difere da maioria por apresentar porte anão e fruto tipo cará. Esses resultados corroboram a alta divergência entre as matrizes de tucumanzeiro-do-pará avaliadas e fornecem indícios de sucesso no intercruzamento entre as alocadas nos grupos distintos, especialmente entre as que compõem os grupos 9; 11 e 15, possibilitando a formação de grupos heteróticos.

No caso da dispersão gráfica (Figura 3), as distâncias genéticas geradas pelos marcadores RAPD confirmaram o posicionamento das matrizes mais distintas $(22 ; 4 ; 19$ e 1$)$, como também a forte divergência genética entre as matrizes, pois se posicionaram de forma dispersa no eixo bidimensional, tendo ainda identificado outras matrizes divergentes $(15 ; 29 ; 23 ; 24 ; 6 ; 9 ; 16 ; 18 ; 20 ; 21 ; 26 ; 27$ e 28$)$, o que ratifica os resultados obtidos pelos métodos anteriores. Porém, os três primeiros componentes explicaram apenas $22,26 \%$ da variação entre as amostras, sendo necessários 19 autovalores para responder por $81 \%$ da variação. Sera et al. (2003), ao avaliarem 14 genótipos elites de café por marcadores RAPD, constataram que as três primeiras coordenadas foram responsáveis por $53,8 \%$ da variação dos dados. Por sua vez, Arriel et al. (2006) obtiveram 35,13\% de variação em 35 genótipos de gergelim. Com base no exposto, acredita-se que a dispersão gráfica conseguiu representar, de alguma forma, a variabilidade genética existente entre as matrizes de tucumã.

Os grupos formados pelo dendrograma obtido pelo método UPGMA foram distintos dos formados pelo método de Tocher. Daher et al. (2002), utilizando essas mesmas metodologias em coqueiro, encontraram resultados semelhantes ao apresentado neste trabalho, em que apenas um dos grupos formados pelo método de Tocher foi coincidente com os grupos da metodologia UPGMA. Arriel et al. (2006) ressaltam a utilização de mais de um método de agrupamento, em razão das diferenças na hierarquização, otimização e ordenação dos grupos, pois permite a complementaridade dos mesmos, impedindo que inferências errôneas sejam adotadas na alocação dos materiais, dentro de um determinado subgrupo, e sugerem que os métodos de hierarquização UPGMA e de otimização de Tocher sejam usados em conjunto.

De modo geral, os resultados dão conta de que os marcadores RAPD se mostraram eficientes na quantificação da variabilidade e da divergência genética entre as matrizes selecionadas para a produção de frutos, expressando que as mesmas apresentam variabilidades e divergências genéticas entre si a serem exploradas. As informações obtidas permitem sugerir que essas matrizes podem ser utilizadas na formação de população-base para o início de um programa de melhoramento genético dessa palmeira. Esse grupo de plantas, além de produtivo e divergente, mostrou variações para outras características agronômicas, como precocidade, tamanho e coloração de frutos maduros. Assim sendo, sugerese a utilização das matrizes que formaram grupos isolados como potenciais genitores em programas de melhoramento que explorem a heterose ao mercado de frutos. Um exemplo é a planta-matriz 22, a mais divergente e que também possui características agronômicas desejáveis, devendo ser recomendada em intercruzamentos com as demais matrizes, especialmente as matrizes $4 ; 16 ; 25$ e 28 .

Pode-se também aventar que, desse grupo de plantas-matrizes, representantes do BAG-Tucumã da Embrapa Amazônia Oriental, não foram encontradas duplicadas, muito embora algumas delas partilhem o mesmo genitor materno. 
TABELA 1 - Principais características agronômicas das 29 plantas-matrizes de tucumanzeiro-do-pará selecionadas no BAG - Tucumã da Embrapa Amazônia Oriental.

\begin{tabular}{|c|c|c|}
\hline Planta-matriz & Procedência & Principais características agronômicas \\
\hline 1 & Marapanim - PA & Pouco perfilho, produção de 8,6 kg, tipo comum, alaranjado. \\
\hline 2 & Marudá - PA & Médio perfilho, produção de 12,6 kg, tipo comum, alaranjado. \\
\hline 3 & Marudá - PA & Alto perfilho, produção de $7,3 \mathrm{~kg}$, tipo comum, alaranjado. \\
\hline 4 & Marudá - PA & Pouco perfilho, produção de 17,3 kg, tipo comum, vermelho. \\
\hline 5 & Marudá - PA & Pouco perfilho, produção de 7,4 kg, tipo comum, vermelho. \\
\hline 6 & Marapanim - PA & Pouco perfilho, produção de 11,5 kg, tipo comum, alaranjado. \\
\hline 7 & Marapanim - PA & Pouco perfilho, produção de $10,5 \mathrm{~kg}$, tipo comum, alaranjado. \\
\hline 8 & Curuçá - PA & Pouco perfilho, produção de 12,0 kg, tipo comum, alaranjado. \\
\hline 9 & Curuçá - PA & Alto perfilho, produção de 12,7 kg, tipo comum, alaranjado. \\
\hline 10 & Curuçá - PA & Pouco perfilho, produção de 16,9 kg, tipo comum, vermelho. \\
\hline 11 & Curuçá - PA & Médio perfilho, produção de 9,6 kg, tipo comum, alaranjado. \\
\hline 12 & Curuçá - PA & Médio perfilho, produção de $10,5 \mathrm{~kg}$, tipo comum, alaranjado. \\
\hline 13 & Curuçá - PA & Alto perfilho, produção de 13,3 kg, tipo comum, vermelho. \\
\hline 14 & Maracanã - PA & Pouco perfilho, produção de 14,0 kg, tipo comum, alaranjado. \\
\hline 15 & Maracanã - PA & Pouco perfilho, produção de 10,1 kg, tipo comum, alaranjado. \\
\hline 16 & Maracanã - PA & Alto perfilho, produção de $20,3 \mathrm{~kg}$, tipo comum, alaranjado. \\
\hline 17 & Maracanã - PA & Médio perfilho, produção de $15,0 \mathrm{~kg}$, tipo comum, alaranjado. \\
\hline 18 & Salinópolis - PA & Pouco perfilho, produção de 15,5 kg, tipo grande, alaranjado. \\
\hline 19 & Salinópolis - PA & Pouco perfilho, produção de 12,0 kg, tipo grande, vermelho. \\
\hline 20 & Salinópolis - PA & Médio perfilho, produção de 7,8 kg, precoce, alaranjado. \\
\hline 21 & Salinópolis - PA & Pouco perfilho, produção de 7,3 kg, precoce, amarelo. \\
\hline 22 & Salinópolis - PA & Pouco perfilho, produção de $11,5 \mathrm{~kg}$, precoce, amarelo. \\
\hline 23 & Salinópolis - PA & Pouco perfilho, produção de 13,5 kg, precoce, amarelo. \\
\hline 24 & Salinópolis - PA & Médio perfilho, produção de 11,1 kg, precoce, alaranjado. \\
\hline 25 & Bragança - PA & Pouco perfilho, produção de 6,9kg, tipo cará, vermelho. \\
\hline 26 & Bragança - PA & Médio perfilho, produção de 10,2 kg, tipo cará, alaranjado. \\
\hline 27 & Bragança - PA & Médio perfilho, produção de $6,2 \mathrm{~kg}$, tipo cará, amarelo. \\
\hline 28 & Bragança - PA & Alto perfilho, produção de $14,6 \mathrm{~kg}$, tipo anã e cará, alaranjado. \\
\hline 29 & Bragança - PA & Alto perfilho, produção de $13,3 \mathrm{~kg}$, tipo anã e cará, alaranjado. \\
\hline
\end{tabular}

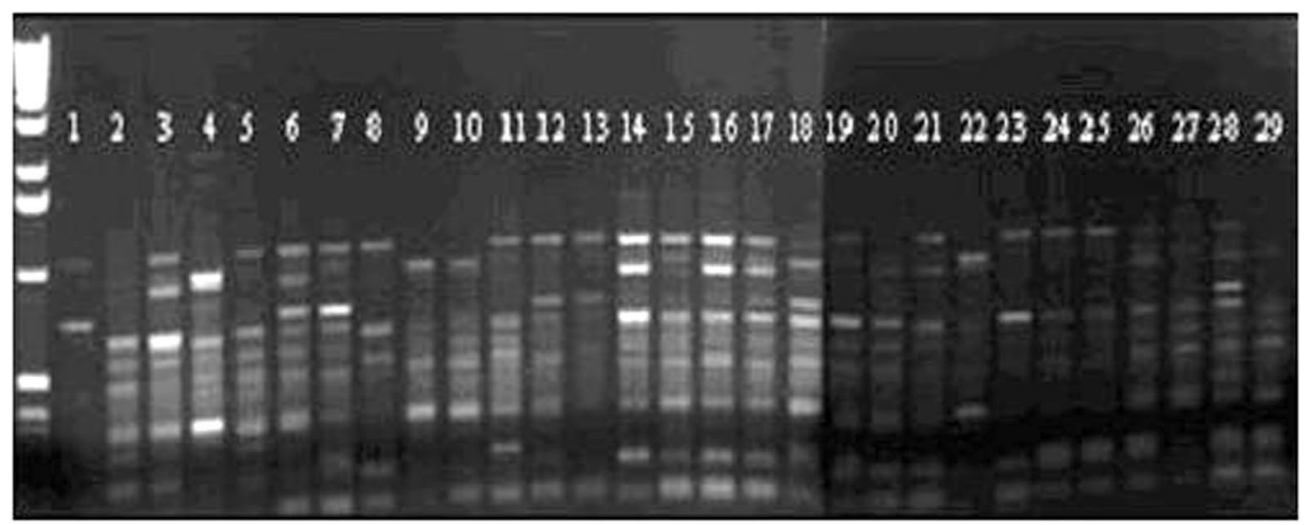

FIGURA 1 -Perfil do gel de agarose demonstrando o polimorfismo gerado pelo primer OPAB-04 nas 29 plantas-matrizes de tucumã-do-pará. 
TABELA 2 - Nível de polimorfismo obtido para os 24 iniciadores RAPD utilizados na análise de divergência genética entre as 29 plantas-matrizes de tucumanzeiro-do-pará.

\begin{tabular}{|c|c|c|c|c|}
\hline Primer & Sequência $5^{\prime}=>3^{\prime}$ & NBP & NTB & $\begin{array}{c}\text { Polimorfismo } \\
(\%)\end{array}$ \\
\hline OPA-08 & 5' GTGACGTAGG 3' & 08 & 09 & 88,9 \\
\hline OPA-11 & 5' CAATCGCCGT 3' & 15 & 15 & 100 \\
\hline OPA-14 & 5' TCTGTGCTGG 3' & 09 & 09 & 100 \\
\hline OPA-19 & 5' CAAACGTCGG 3' & 15 & 16 & 93,8 \\
\hline OPAB-01 & $5^{\prime}$ ТТССССАCСC 3' & 18 & 19 & 94,7 \\
\hline OPAB-04 & 5' GGCACGCGTT 3' & 19 & 19 & 100 \\
\hline OPAB-08 & 5' GTTACGGACC 3' & 19 & 19 & 100 \\
\hline OPAB-19 & 5' ACACCGATGG 3' & 18 & 18 & 100 \\
\hline OPAB-20 & 5' CTTCTCGGAC 3' & 15 & 15 & 100 \\
\hline OPAR-07 & 5' TCCTTCGGTG 3' & 07 & 07 & 100 \\
\hline OPAZ-04 & 5' CCAGCCTCAG 3' & 17 & 17 & 100 \\
\hline OPAZ-05 & 5' TCCGCATACC 3' & 21 & 21 & 100 \\
\hline OPAZ-11 & 5' TCCAGCGCGT 3' & 10 & 10 & 100 \\
\hline OPAZ-18 & 5' CCGACGTTGA 3' & 11 & 11 & 100 \\
\hline OPB-02 & 5' TGATCCCTGG 3' & 15 & 15 & 100 \\
\hline OPB-05 & 5' TGCGCCCTTC 3' & 15 & 15 & 100 \\
\hline OPJ-13 & 5' CCACACTACC 3' & 12 & 12 & 100 \\
\hline OPN-20 & 5' CGTGCTCCGT 3' & 15 & 15 & 100 \\
\hline OPO-03 & 5' CTGTTGCTAC 3' & 13 & 13 & 100 \\
\hline OPO-12 & 5' CAGTGCTGTG 3' & 10 & 12 & 83,3 \\
\hline OPU-05 & 5' TTGGCGGCCT 3' & 09 & 09 & 100 \\
\hline OPU-06 & 5' ACCTTTGCGG 3' & 17 & 17 & 100 \\
\hline OPU-10 & 5' ACCTCGGCAC 3' & 11 & 11 & 100 \\
\hline OPU-17 & 5'ACCTGGGGAG 3' & 08 & 08 & 100 \\
\hline Total & & 327 & 332 & - \\
\hline Média & & 13,6 & 13,8 & 98,5 \\
\hline
\end{tabular}

NBP: número de bandas polimórficas; NTB: número total de bandas.

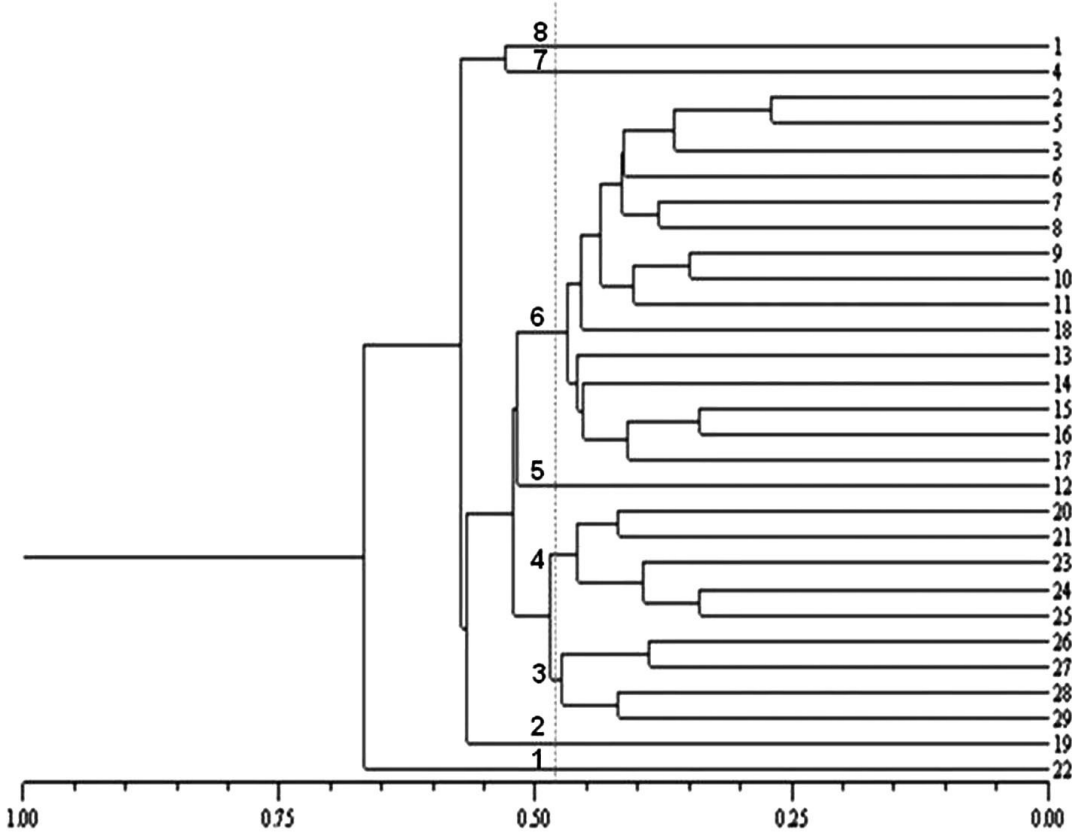

FIGURA 2- Dendrograma das dissimilaridades genéticas entre as 29 plantas-matrizes de tucumanzeirodo-pará, gerado pelo método UPGMA a partir de 327 marcadores RAPD, com base no coeficiente de Jaccard $(=0,517)$. 
TABELA 3 - Dissimilaridades genéticas mínimas, máximas e médias obtidas para as 29 matrizes de tucumanzeiro-do-pará por meio de 327 marcadores RAPD.

\begin{tabular}{cccc}
\hline \multirow{2}{*}{ Planta-matriz } & \multicolumn{3}{c}{ Dissimilaridades } \\
\cline { 2 - 4 } & Mínima & Máxima & Média \\
\hline 1 & 0,457 & 0,676 & 0,561 \\
2 & 0,269 & 0,655 & 0,467 \\
3 & 0,364 & 0,672 & 0,503 \\
4 & 0,467 & 0,668 & 0,588 \\
5 & 0,269 & 0,711 & 0,468 \\
6 & 0,374 & 0,672 & 0,496 \\
7 & 0,352 & 0,697 & 0,484 \\
8 & 0,368 & 0,672 & 0,477 \\
9 & 0,347 & 0,594 & 0,492 \\
10 & 0,347 & 0,658 & 0,474 \\
11 & 0,394 & 0,672 & 0,481 \\
12 & 0,456 & 0,698 & 0,554 \\
13 & 0,417 & 0,661 & 0,499 \\
14 & 0,421 & 0,678 & 0,524 \\
15 & 0,337 & 0,678 & 0,483 \\
16 & 0,337 & 0,715 & 0,511 \\
17 & 0,390 & 0,700 & 0,508 \\
18 & 0,420 & 0,643 & 0,490 \\
19 & 0,451 & 0,675 & 0,573 \\
20 & 0,421 & 0,686 & 0,502 \\
21 & 0,421 & 0,667 & 0,515 \\
22 & 0,582 & 0,715 & 0,668 \\
23 & 0,369 & 0,701 & 0,513 \\
24 & 0,339 & 0,683 & 0,493 \\
25 & 0,339 & 0,654 & 0,488 \\
26 & 0,393 & 0,640 & 0,517 \\
27 & 0,393 & 0,646 & 0,531 \\
28 & 0,422 & 0,646 & 0,558 \\
29 & 0,422 & 0,682 & 0,517 \\
\hline Geral & 0,269 & 0,715 & \\
\hline
\end{tabular}

TABELA 4 - Grupos formados pelo método de otimização de Tocher, a partir das dissimilaridades genéticas obtidas entre as 29 plantas-matrizes de tucumanzeiro-do-pará por meio de 327 marcadores RAPD.

\begin{tabular}{cc}
\hline Grupos & Plantas-matrizes \\
\hline 1 & 1 e 2 \\
2 & 3 e 5 \\
3 & 4 e 6 \\
4 & 7 e 9 \\
5 & 8 e 10 \\
6 & 11 e 13 \\
7 & 12 e 14 \\
8 & 15 e 17 \\
9 & 16 e 18 \\
10 & 19 e 21 \\
11 & 20 e 22 \\
12 & 23 e 25 \\
13 & 24 e 26 \\
14 & 27 e 29 \\
15 & 28 \\
\hline
\end{tabular}




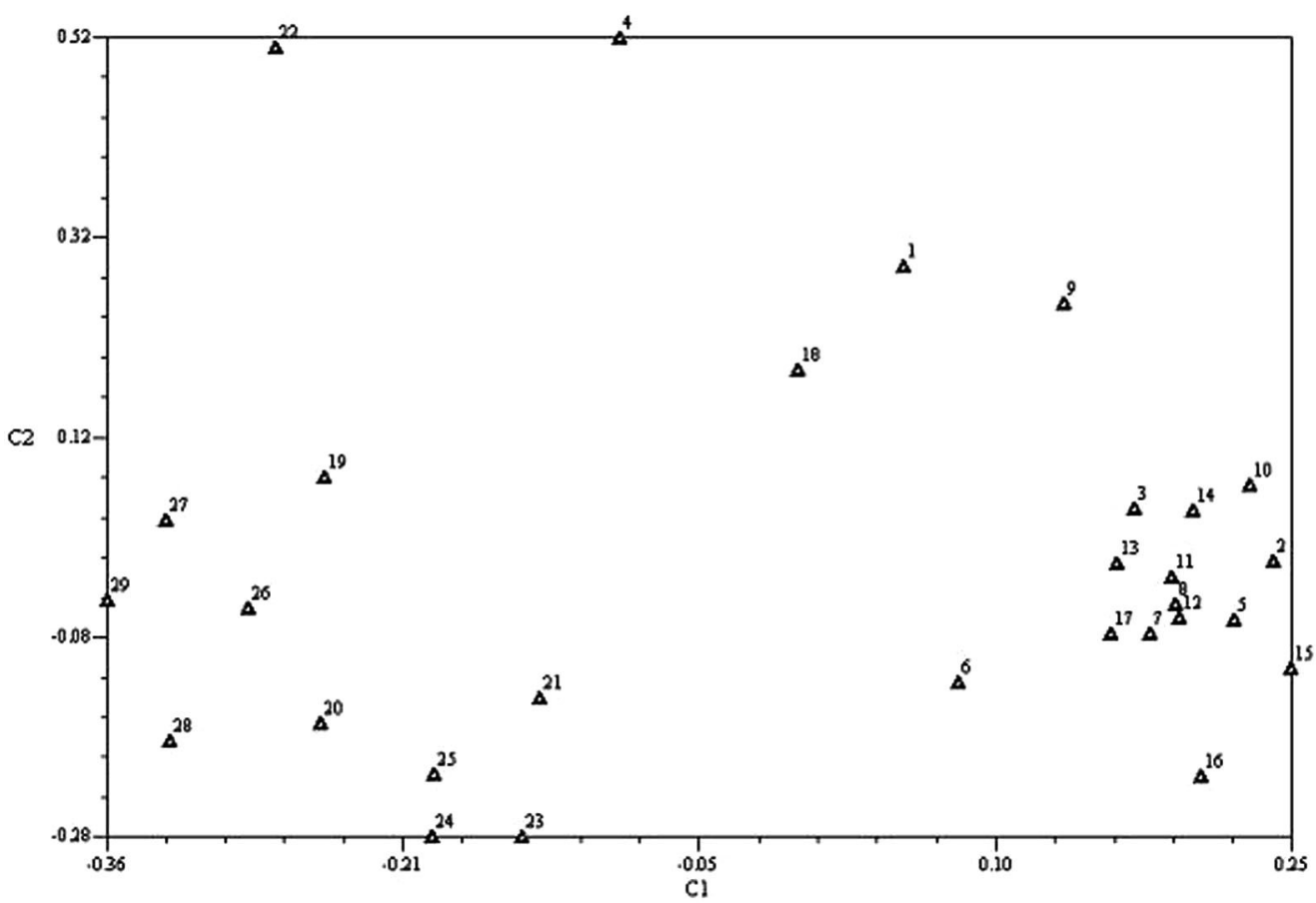

FIGURA 3 - Dispersão gráfica das 29 plantas-matrizes de tucumanzeiro-do-pará baseada na matriz de dissimilaridades genéticas obtidas por 327 marcadores RAPD.

\section{CONCLUSÕES}

1-Os genótipos de tucumanzeiro-do-pará, promissores para a produção de frutos avaliados por marcadores RAPD, apresentam considerável variabilidade e divergência genética, o que demonstra a importância de técnicas moleculares em subsidiar programas de melhoramento.

2-Os métodos de agrupamentos apresentam pouca concordância na alocação das matrizes e devem ser utilizados como complemento na identificação de grupos divergentes.

\section{AGRADECIMENTOS}

Aos auxiliares de campo da Embrapa Amazônia Oriental, pelo auxílio na coleta dos folíolos, e aos do Laboratório de Genética Molecular dessa instituição, pela ajuda na realização das reações. Ao CNPq, pela concessão de bolsa à primeira autora.

\section{REFERÊNCIAS}

ARRIEL, N. H. C.; DI MAURO, A. O.; DI MAURO, S. M. Z.; BAKKE, O.A.; UNÊDA-TREVISOLI, S.H.; COSTA, M.M.; CAPELOTO, A.; CORRADO, A.R. Técnicas multivariadas na determinação da diversidade genética em gergelim, usando marcadores RAPD. Pesquisa Agropecuária Brasileira, Brasília, v.41, n.5, p.801-809, 2006.

BICALHO, K. C.; OLIVEIRA, L. E. M de; SANTOS, J. B. dos; MESQUISTA, A. C.; MENDONÇA, E. G. Similaridade genética entre clones de seringueira (Hevea brasiliensis) por meio de marcadores RAPD. Ciência \& Agrotecnologia, Lavras, v.32, n. 5, p.1510-1515, set./out., 2008.

CAIXETA, E.T.; OLIVEIRA, A.C.B.; BRITO, G.G.; SAKIYAMA, N.S. Tipos de marcadores moleculares. In: BORÉM, A.; CAIXETA, E.T. (Ed.). Marcadores moleculares. Viçosa: UFV, 2006. p. 9-78.

CLEMENT, C. R.; LLERAS PÉREZ, E.; VAN LEEUWEN, J. O potencial das palmeiras tropicais no Brasil: acertos e fracassos das últimas décadas. Agrociências, Montevideu, v. 9, n.1-2, p. 67-71. 2005. 
Costa, M. R.; OliveirA, M. do S. P. de. Extração de DNA de açaizeiro a partir de folhas. Belém: EMBRAPA-CPATU, 2002. 22p. (Documentos, 127).

CRUZ, C.D.; REGAZZI, A. J.; CARNEIRO, P. C. S. Modelos biométricos aplicados ao melhoramento genético. Viçosa: UFV, 2004. 480p.

CYMERSYS, M. Tucumã-do-pará. In: SHANLEY, P.; MEDINA, G. Frutíferas e plantas úteis na vida Amazônica. Belém : CIFOR, Imazon, 2005. p. 209-214.

DAHER, R.F.; PEREIRA, M.G.; TUPINAMBÁ, E.A.; JÚNIOR, A.T. A.; ARAGÃO, W.M.; RIBEIRO, F.E.; OLIVEIRA, L. O.; SAKIYAMA, N. S. Assessment of coconut tree genetic divergence by compound sample RAPD marker analysis. Crop Breeding and Applied Biotechnology, Londrina, v. 2, p. 431-438, 2002.

DIAS, L.A dos S.; KAGEYAMA, P. Y.; CASTRO, G. C. T. Divergência genética multivariada na preservação de germoplasma de cacau (Theobroma cacao L.). Agrotrópica, Itabuna, v. 9, p. 29-40, 1997.

DOYLE, J. J.; DOYLE, J. L. A rapid DNA isolation procedure for small quantities of fresh leaf tissue. Phytochemistry, Amsterdam, v.19, p.11-15, 1987.

GARCIA, B.F. Estimation of genetic distances among green pepper (Capsicum annuиm L.) lines using RAPD markers and its relationship with heterosis. In: INTERNATIONAL PEPPER CONFERENCE, 16., 2002, Tampico, 2002. Proceedings... p.37-40.

GRATTAPAGLIA, D. Aplicações operacionais de marcadores. In: BORÉM, A. (Ed.). Biotecnologia florestal. Viçosa: UFV, 2007. p 175-200.

INSENSEE, J. M. F.; VIDAL, P. O.; GAIOTTO, F. A. Caracterização genética entre pupunheiras cultivadas no Sul da Bahia por marcadores RAPD. Magistra, Cruz das Almas, v. 19, n. 4, p. 304-310, 2007.

LIMA, R. R.; COSTA, J. P. C da. Registro de introduções de plantas de cultura pré-colombiana coletadas na Amazônia Brasileira. Belém: EMBRAPA-CPATU, 1991. 191 p. (Documentos, 58).
LLERAS, E.; GIACOMETTI, D.C.; CORADIN, L. Áreas críticas de distribución de palmas de las Americas para coleta, evaluación y conservación. In: INFORME DE LA REUNION DE CONSULTA SOBRE PALMERAS POCO UTILIZADAS DE AMERICA TROPICAL, 1983, San Jose. Anales... San Jose: CATIE/FAO, 1983. p. 67-81.

JUNQUEIRA, K. P.; FALEIRO, F. G.; BELLON, G.; JUNQUEIRA, N. T. V.; FONSECA, K. G da; LIMA, C. A. de; SANTOS, E. C. dos. Variabilidade genética de acessos de pitaya com diferentes níveis de produção por meio de marcadores RAPD. Revista Brasileira de Fruticultura, Jaboticabal, v.32, n.3, p.840-846, 2010.

OLIVEIRA, M. do S.P. de; AMORIM, E. P.; SANTOS, J.B. dos; FERREIRA, D.F. Diversidade genética entre acessos de açaizeiro baseada em marcadores RAPD. Ciência \& Agrotecnologia, Lavras, v.31, n. 6, p.1645-1653, 2007.

OLIVEIRA, N. P. de; OLIVEIRA, M. do S. P. de; MOURA, E. F. Seleção de marcadores RAPD para análise genética em germoplasma de tucumã-do-Pará (Astrocaryum vulgare Mart.). In: CONGRESSO BRASILEIRO DE MELHORAMENTO DE PLANTAS, 5., 2009, Guarapari. Anais... Vitória: Incaper, 2009. v. 1, p. 1-4. CD-ROM.

REIF, J. C.; MELCHONGER, A. E.; FRISCH, M. Genetical and mathematical properties of similarity and dissimilarity coefficients applied in plant breeding and seed bank management. Crop Science, Madison, v.45, n. 1, p. 1-7, 2005.

ROHLF, F. J. Numerical taxonomy and multivariate analysis system. New York: Exeter Software, 2000. 38p. (version 2.1)

ROSSATO M.; BARBIERI, R.L.; SCHÄFER, A.; ZACARIA, J. Caracterização molecular de populações de palmeiras do gênero Butia do Rio Grande do Sul através de marcadores ISSR. Magistra, Cruz das Almas, v.19, n. 4, p. 311-318, 2007.

SERA, T.; RUAS, P.M.; RUAS, C de F.; DINIZ, L.E.C.; CARVALHO, V. de P.; RAMPIM, L.; RUAS, E.A.; SILVEIRA, S.R da. Genetic polymorphism among 14 elite Coffea arabica L. cultivars usisg RAPD associated with restriction digestion. Genetics and Molecular Biology, Ribeirão Preto, v. 26, p. 59-64, 2003. 
SERRA, A. G. P.; PAIVA, R.; PAIVA, E.; NOGUEIRA, R.C.; SOARES, F.P.; PAIVA, P.D. de O. Estudo da divergência genética em castanha-do-brasil (Bertholletia excelsa H.B.K) utilizando marcadores moleculares RAPD (Random Amplied Polymorfhic DNA). Magistra, Cruz das Almas, v.18, n. 1, p. 42-47. 2006.

SNEATH, P.H.A.; SOKAL, R.R. Numerical taxonomy. San Francisco: Freeman, 1973.

VILELA-MORALES, E. A.; VALOIS, A. C. C.; NASS, L. L. Recursos genéticos vegetales. Brasília: CENARGEN, 1997. 78p.
VILLACHICA, H.; CARVALHO, J. E. U.; MÜLLER, C. H.; DÍAZ, S. C.; ALMANZA, M. Frutales y hortalizas promisorios de la Amazonia. Lima: FAO, 1996. p. 264-267. (TCA-SPT, 44)

WELSH, J.; McCLELLAND, M. Fingerprinting genomes using PCR with arbritary primers. Nucleic Acids Research, London, v. 18, p. 7213-7218, 1990.

WILLIAMS, J.G.K.; KUBELIK, A.R.; LIVAK, K.J.; RAFASKI, J.A.; TINGEY, S.V. DNA polymorphisms amplified by arbitrary primers are useful as genetic markers. Nucleic Acids Research, London, v. 18, p. 6531-6535, 1990 